https://doi.org/10.46344/JBINO.2021.v10i2b.11

\title{
STRATEGY FOR IMPROVING FINANCIAL EFFICIENCY IN RS.ORTOPEDI PROF. DR. R. SOEHARSO SURAKARTA THROUGH THE ALLIANCE OF PROCUREMENT OF GOODS AND VERTICAL HOSPITALS, SE JOGLO SEMAR.
}

\author{
${ }^{1}$ Subur, ${ }^{2}$ I. Nazaruddin, ${ }^{2}$ F. Pribadi \\ Hospital Administration Management Study Program (Mars), Graduate Program, \\ Muhammadiyah University Of Yogyakarta
}

\begin{abstract}
Background: Hospital. Prof. Orthopedics. Dr. R Soeharso Surakarta is the Technical Implementation Unit (UPT) of the Indonesian Ministry of Health. according to Decree of the Minister of Health Number: 756 / Minister of Health / SK / VI / 2007, Regarding the Decree of 15 (fifteen) Hospitals (UPT) Technical Implementation Units of the Ministry of Health of the Republic of Indonesia which use the Financial Management Pattern Public Service Agency (PPK BLU). The procurement consolidation alliance needs to be carried out at Prof. Orthopedic Hospital. Dr. R. Soeharso Surakarta because it has several benefits, including: Reducing the number of procurement activities, Efficient time and resources in the procurement process, Increasing the bargaining position of users as buyers, reducing procurement risks, growing and developing local industries / local providers and increasing economies of scale (economies of scale). The principle is efficiency in management without reducing the quality of goods / services required. Thus, consolidation of procurement packages can be carried out as long as they provide more value from a technical, financial and benefit perspective compared to procurement done individually.

Purpose: To determine strategies for increasing financial efficiency at Prof. Orthopedic Hospital. Dr. R. Soeharso Surakarta through a consolidation alliance in the procurement of goods and services for vertical hospitals in Joglo Semar .

Methods: This study is a mix methods research, which is a research step by combining two forms of research approaches, namely qualitative and quantitative. The quantitative approach is used to analyze the price of goods before the consolidation alliance with the price of goods after the consolidation alliance for the procurement of goods and services, as well as to determine the increase in financial efficiency in hospitals through the consolidation alliance for the procurement of goods and services at Se Joglo Semar Vertical Hospital. Meanwhile, a qualitative approach is to dig deeper regarding the strengths, weaknesses, suggestions and improvements regarding the consolidation alliance for the procurement of hospital goods and services. This analysis is carried out as a form of Univariate analysis. This descriptive analysis is a data processing that starts from the tabulation process into easy to understand and interpret data. Descriptive analysis with data presentation such as the form of frequency distribution tables and histograms. This is to determine the difference in the unit price between before the consolidation alliance is carried out in the procurement of goods and services and after the consolidation alliance is carried out. The analysis was carried out by using the Hypothesis T-test with the condition that the data were normally distributed. Then if the data is not normally distributed, the
\end{abstract}


analysis is carried out using the Mann-Whitney Hypothesis Test for 2 Unpaired Groups and the Wilcoxon Hypothesis Test if 2 Groups are Paired (Dahlan , 2004).

Results: The Wilcoxon test results obtained p-value or probability value $<0.05$, so it can be concluded that the research hypothesis is accepted (accepts H1) and rejects H0 which means there is a difference between before consolidation and after consolidation.

Conclusion: There are differences in financial efficiency and effectiveness between before and after the Consolidated Goods and Services Procurement Alliance.

Keywords: Financial Efficiency, Consolidation Alliance, Procurement of Goods and Services

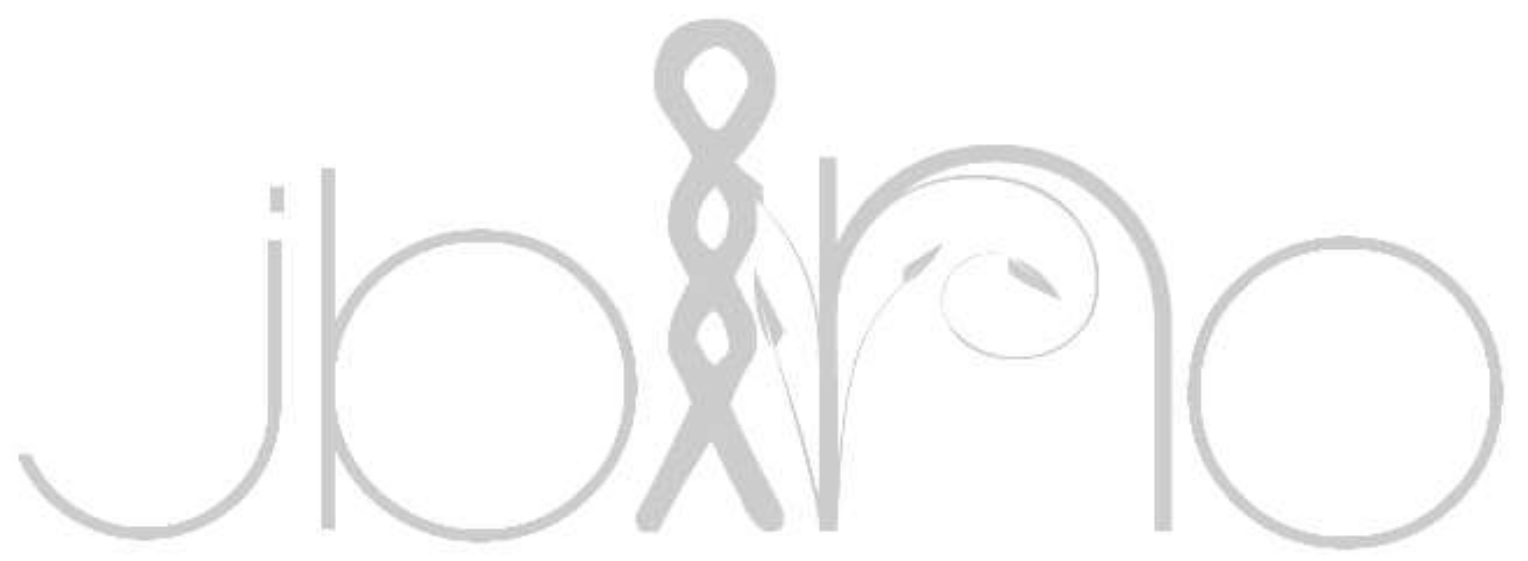




\section{PRELIMINARY}

Hospital. Prof. Orthopedics. Dr. R Soeharso Surakarta is the Technical Implementation Unit (UPT) of the Indonesian Ministry of Health. according to Decree of the Minister of Health Number: 756 / Minister of Health / SK / VI / 2007, Regarding the Decree of 15 (fifteen) Hospitals (UPT) Technical Implementation Units of the Ministry of Health of the Republic of Indonesia which use the Financial Management Pattern. Public Service Agency (PPK BLU).

In Budget 2019 RS Orthopedics Prof. Dr. R. Soeharso Surakarta as Rome S akit that M andiri along with 5 (five) Rome $\mathrm{S}$ akit another means all operating costs and investment in Rome Hospital borne or financed by the Rome $\mathrm{S}$ akit itself derived from Non Tax Revenue Service Agency General Hospital (PNBP BLU), because it only receives expenditures for Civil Servants (PNS) whose funds are from the State Revenue \& Expenditure Budget (APBN).

Besides that, the price of implants is still high (inefficiency) before the consolidation of goods and services procurement alliance because the price of implants with the same brand and type can differ between Vertical Hospitals in JOGLO SEMAR depending on the negotiation ability of each hospital, with the existence of the Consolidated Alliance. Procurement of goods and services (PBJ ), will be very useful because the price of implants with the same brand and type will cost the same among Vertical Hospitals in JOGLO SEMAR. and will be lower (more efficient) So that hopefully there will be financial efficiency at Prof. Orthopedic Hospital. DR. R. Soeharso Surakarta, as well as increasing the efficiency of operational costs, therefore it is necessary to innovate an efficiency improvement strategy, through a consolidated goods and services procurement alliance (PBJ).

This strategy of the Goods \& Services Procurement Consolidation Alliance is urgently needed, because first, the state budget funds from the government are increasingly limited, while health costs are increasing. both Government Hospitals are encouraged to be more independent, so that they can finance operational expenditures and even investments that must be handled by the hospital themselves. The third order to be self-reliance Hospital will require innovation efficiency policy strategy one implant expenditure budget implant because about $19 \%$ of the revenue target in 2020 . The fourth is something new about the alliance consolidation of procurement of goods and services in the process of procurement of goods and services in the environment Vertical Hospitals throughout Indonesia, as (pilot project) in the region as JOGLO SEMAR.

Because of all the operational and investment costs R SOrtopedi Prof. Dr. R. Soeharso Surakarta is in charge and financed by the Hospital itself or independently causing the need for a special strategy to optimize the hospital's financial condition so that it can maintain and manage finances as well as possible so that the operation of the hospital can still exist to provide health services to the community for that we need a Strategy to Improve Financial Efficiency in Prof. Orthopedic Hospital. Dr. R. Soeharso Surakarta through the Goods and Services Procurement Consolidation Alliance.

The procurement consolidation alliance needs to be carried out at Prof. Orthopedic Hospital. Dr. R. Soeharso Surakarta because it has several benefits, including: Reducing the number of procurement activities, Efficient time and resources in the procurement process, Improving the 
bargaining position of the user ( user ) as a buyer, Reduce the risk of procurement, Cultivate local industry / local providers and Improving economies of scale ( economies of scale ). The principle is efficiency in management without reducing the quality of goods / services required, so that consolidation of procurement packages can be carried out as long as they provide more value from a technical, financial and benefit perspective compared to procurement done individually. This shows why this research needs to be done.

Elmu ti , et .al (2001) describes the strategic alliance is a collaboration of some of ter Achieve profitable her goal. Konsolidasi a kegiatan used mem Strengthen, unite to Achieve the desire of the company. Procurement activities ( procurement), according to Bailey et al. (2015), are a process that includes the provision of goods and services needed in the quantity and quality desired, originating from the appropriate source, sent to the intended place at the right price. Collaborative procurement consolidation is a strategy that is seen as a horizontal collaboration in the form of a unification of purchasing activity functions between two or more organizations ( Essig, 2000). A budget is an existing planning in an organization that is compiled appropriately and described in detail in a monetary unit for a certain period of time. Munandar (2011) says that this budget is a plan that is systematically compiled which includes all company activities that apply to the period of time. determined . Meanwhile, Nafarin (2002) also explains that this budget is a written plan or strategy of an organization that is stated in quantitative form within a certain period of time. According to Mardiasmo (2004) to measure the efficiency can use you right ratio between revenue operations compared with operational costs. The greater the pressure is the higher the level of efficiency.

\section{METHOD}

This research is a mixed method research, which is a research step by combining two approaches in research, namely qualitative and quantitative. The quantitative approach is used to analyze the price of goods before the consolidation alliance with the price of goods after the consolidation alliance for the procurement of goods and services, as well as to determine the increase in financial efficiency in hospitals through the consolidation alliance for the procurement of goods and services at Se Joglo Semar Vertical Hospital. Meanwhile, a qualitative approach is to dig deeper regarding the strengths, weaknesses, suggestions and improvements regarding the consolidation alliance for the procurement of hospital goods and services. The subjects in this study were inventory purchase data before and after using the consolidation alliance method of procurement of goods and services. Where in 2018 the consolidation alliance method has not been used and in 2019 the Consolidated alliance method with 5 vertical hospitals (Ministry of Health) has been used. The one in Central Java, SE JOGLO SEMAR, which consists of Sarjito Hospital, RS. Klaten .RS. Prof. Orthopedics. Dr. R. Soeharso Surakarta. RS. The soul of Magelang . RSUP. DR. Kariadi Semarang. The object of this research is financial efficiency at Prof. Orthopedic Hospital. Dr. R. Soeharso Surakarta.

The population in this study is the procurement of implant equipment available at RSO. Prof. Dr. R. Soeharso from 2018 to 2019. The sampling technique used in this study was to use the Porpusive Sampling technique by referring to the inclusion criteria. The sample inclusion criteria in this study were: Specifications of Goods \& 
Services, Kinds of Goods \& Services, Quantity of Goods \& Services and Prices of Goods \& Services. The variable in this study is the efficiency of the price or cost of procuring goods and services before and after the alliance and consolidation. The instrument in this study used the Observation Table (Attached). In this Observation Table the observations of the data on the procurement of implant devices available at RSO are recorded. Prof. Dr. R. Soeharso before the Consulidation alliance and after the Consulidation alliance where to find out the differences in financial efficiency and effectiveness. Then use the interview sheet to dig deeper regarding the strengths, weaknesses, suggestions and improvements regarding the consolidation of the procurement of hospital goods and services. This analysis is carried out as a form of Univariate analysis. This descriptive analysis is a data processing that starts from the tabulation process into easy to understand and interpret data. Descriptive analysis with data presentation such as the form of frequency distribution tables and histograms. This is to determine the difference in the unit price between before the consolidation alliance is carried out in the procurement of goods and services and after the consolidation alliance is carried out. The analysis was carried out by using the Hypothesis T-test with the condition that the data were normally distributed. Then if the data is not normally distributed, the analysis is carried out using the Mann-Whitney Hypothesis Test for 2 Unpaired Groups and the Wilcoxon Hypothesis Test if 2 Groups are Paired (Dahlan , 2004).

\section{RESULTS}

\section{Distribution of Frequency of Expenditure Data Before Consolidation}

The data on goods expenditure before consolidation shows the mean = 26137609.0909 and Standard Deviation = 37286076.45330. The frequency distribution of expenditure data before consolidation can be presented in table 4.1 as follows:

Table 4.1 Distribution of Frequency of Expenditure Data Before Consolidation .

\begin{tabular}{lll}
\hline Shopping Data & Mean & Std. Deviation \\
\hline $\begin{array}{l}\text { Before } \\
\text { Consolidation }\end{array}$ & 26137609.0909 & 37286076.45330 \\
\hline
\end{tabular}

\section{Distribution of Frequency of Expenditure Data After Consolidation}

After consolidation data on goods expenditures, the results obtained Mean = 16430481.8182 and Standard Deviation $=$ 23734722.26555. The frequency distribution of expenditure data after consolidation can be presented in table 4.2 as follows:

Table 4.2 Distribution of Frequency of Expenditure Data After Consolidation.

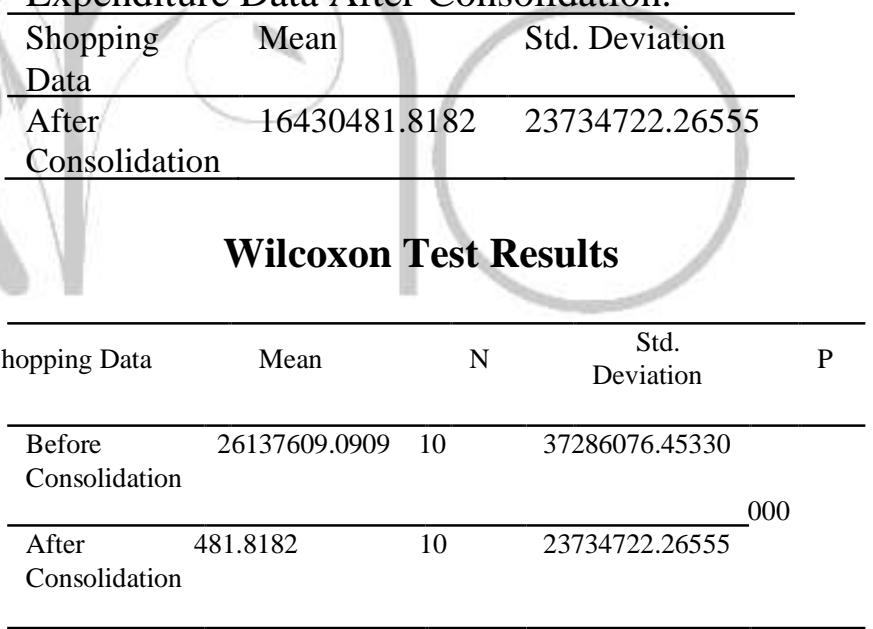

obtained p-value or probability value $<0.05$, so it can be concluded that the research hypothesis is accepted (accepts H1) and rejects $\mathrm{Ho}$ o. which means that there is a difference between before consolidation and after consolidation. 


\section{DISCUSSION}

Based on the results of data collection on the 110 available goods expenditures, it is known that the mean or mean value of spending before consolidation is 26 , $137,609,0909$ and the standard deviation value is 37286076.45330 . Of the 110 goods expenditures, the mean value or average after consolidation expenditure is 16430481.8182 and the standard deviation value is 23734722.26555 . From the results of data collection, the mean or average and standard deviation shows that the level of procurement spending has decreased or been lower in its financing.

The results showed that the significant value Wilcoxon test obtained value of $p$ - Value or a probability value $<0.05$, so it can be concluded the research hypothesis is accepted ( $\mathrm{H} 1$ accept and reject $\mathrm{H}_{0}$ ) means that there are significant differences between before consolidation and after consolidation. This shows that there is a positive correlation between the consolidation method and financial performance.

The description above accepts the hypothesis because there is a difference between before consolidation and after consolidation. Consolidation of procurement needs to be done because it has several benefits, including: Reducing the number of procurement activities, Efficient time and resources in the procurement process, improve the bargaining position of the user ( user ) as a buyer, Reduce the risk of procurement, Cultivate local industry / local providers and Improving economies of scale ( economies of scale). The principle is efficiency in management without reducing the quality of goods / services required. Thus, consolidation of procurement packages can be carried out as long as they provide more value from a technical, financial and benefit perspective compared to procurement done individually.

The results of this study are supported by the theory put forward by Johnson (1999), that one of the advantages of consolidation is increased efficiency through reducing procurement transaction costs and increasing economies of scale through the combination of purchase quantities.

Based on the answers from several doctors in charge of services (DPJP) as users in the procurement of goods and services, this states that there is an increase in budget efficiency between before and after the PBJ consolidation Alliance (Procurement of Goods and Services) for the purchase of implants.

Based on the answers from respondents, it was stated that the implementation of implant purchases was in accordance with the needs of the hospital. Then, based on the statements of the respondents, it was stated that the procurement of implant devices with this consolidation strategy was particularly beneficial for hospitals. The benefits felt by the hospital, namely, by combining several packages of procurement of similar goods / services so that the determination of the same price in 4 hospitals, namely RSO Prof. dr. R. Soeharso Surakarta, RSUP. dr. Sardjito Yogyakarta, RS. Soeradji Tirtonegoro Klaten, RSUP. dr. Kariadi Semarang. By determining the same price in each hospital, it will be easier to audit. Then with consolidation can increase bargaining with larger providers and can get implants cheaper because of the large number of orders for the combined needs of the 4 hospitals. 


\section{CONCLUSION}

The results of data collection on the 110 available goods expenditures note that the mean or mean value of expenditures before consolidation is $26,137,609,0909$ and the standard deviation value is 37286076.45330 .

The data collected on 110 shopping goods available is known that the mean or average value of shopping after consolidation amounted 16430481.8182 and standard deviation values of 23734722.26555 .

From the results of data collection, the mean or average and standard deviation shows that the level of procurement spending has decreased or been lower in its financing.

There are differences in financial efficiency and effectiveness between before and after the Consolidated Goods and Services Procurement Alliance.

\section{SUGGESTION}

Based on the conclusion, it can be informed that the Hospital in carrying out the procurement of goods and services should be carried out and maintain the system using a consolidated alliance. D ith the Alliance Consolidated Procurement (PBJ) this would be very useful where can financial efficiency occur and an increase in operating cost efficiency in Orthopedic Hospital Prof. DR. R. Soeharso Surakarta.

\section{RESEARCH LIMITATIONS}

Based on the research that has been carried out, the authors feel there are still limitations to the research, namely in data collection there are still weaknesses in controlling confounding factors even though efforts have been made to control confounding factors. Therefore, the researcher suggests that further research is necessary so that the results of similar studies are even better. .

\section{REFERENCES}

Amel , D., Barnes, C., Panetta, F. and Salleo, C. (2004). Consolidation and efficiency in the financial sector: A review of the international evidence Dean Amel, Colleen Barnes, Fabio Panetta and Carmelo Salleo, vol. 28, issue 10, 2493-2519.

https://www.sciencedirect.com/science/ article/abs/pii/S0378426603002759 (In Access Date 09 June 2020).

Andrew K , 1971. Definition of Strategy and Concept . https://www.hestanto.web.id/pengertianstrategi/ (In Access Date 23 April 2020).

Briggs , AD, and Burn, LR (2018). Hospital purcha sing alliances: Ten years after. https://www.supplychainassociation.org /wp-content/uploads/2018/10/WhartonSchool-Study-on-GPOs.pdf (In Access Date 09 June 2020).

Casciaro , T. (1998) . Determinants of Governance Structure in Alliances: The Role of Strategic, Task and Partner Uncertainties , University of Toronto . https://www-

2.rotman.utoronto.ca/facbios/file/Gover nance.pdf (In Access Date 09 June 2020).

Culpan , R. (2009) A fresh look at strategic alliances: research issues and future directions , vol. 1, issue 1, 4-23. https://www.researchgate.net/publication/24 7836386_A_fresh_look_at_strategic_allianc es_Research_issues_and_future directions ( In Access Date 11 June 2020).

Dahlan S, 200. Statistics For Medicine And Health https://doku.pub/documents/statistik-untukkedokteran-dan-kesehatan-msopiyudin- 
dahlan-30j8pxk4p5lw (In Access Date May 4, 2020).

Elmuti et al ., 2001. Definition of a strategic partnership or strategic alliance. https://www.dictio.id/t/apa-yang-dimaksuddengan-strategic-partnership-atau-aliansistrategis/2357 (In Access Date 23 April 2020).

Hemawan F , 2017. Im plementasi Strategy Konsulidasi In PBJP Through the Catalog Regions.

http://p3i.or.id/implementasi-strategikonsolidasi-dalam-pbjp-melaluikatalog-daerah/ (In Access Date 29 April 2020 ).

Firdha S, 2019. Benefits of Consulidation in Procurement of Goods and Services .

https://www.eproc.id/berita/detail/benef its-konsolid-dalam-pengadaan-barangjasa. (In Access Date 29 April 2020 ).

Hasibuan , 1984 . Definition of Type Purpose Efficiency and Examples . https://www.kanal.web.id/pengertianefisiensi-tujuan-jenis-dan-contohnya (In Access Date 23 April 2020).

Lamothe , M. , \& Lamothe , S. (2000). Beyond the Search for Competition in Social Service Contracting Procurement, Consolidation, and Accountability, Volume: 39 issue: 2, page (s): 164-188, University of Oklahoma, Norman https://journals.sagepub.com/doi/10.1177/02 $\underline{75074008316557}$ (In Access Date 11 June 2020).

Mardiasmo , 2004 . Program Effectiveness . https://www.google.com/search?client=firef ox$\underline{\mathrm{bd} \& \mathrm{q}=\% 28 \mathrm{Mardiasmo}+2004 \% 3 \mathrm{~B} 133 \% 29}$. ( In Access Date 29 April 2020 ).
Mulyamah , 1987. Definition of Type Objective Efficiency and Examples . https://www.kanal.web.id/pengertianefisiensi-tujuan-jenis-dan-contohnya (In Access Date 23 April 2020 ).

Munandar, 2011. Company Budget . https://www.talenta.co/blog/insighttalenta/anggaran-perusahaan/ (In Access Date 23 April 2020 ).

Nafarin , 2000. Company Budget . https://www.talenta.co/blog/insighttalenta/anggaran-perusahaan/ (In Access Date 23 April 2020 ).

Notoatmodjo S, 2005, Health Research Methodology. PT. Rinika Cipta, Jakarta .

Oumlil, A. B and Williams, AJ (2011). Strategic alliances and organizational buying: an empirical study of the healthcare industry , vol. 4, issue 6, 610-626.

https://econpapers.repec.org/article/idsij pman/v 3a4 3ay 3a2011 3ai 3a6 3ap 3a610-626.htm (In Access Date 11 June 2020).

Pratono , A. , and Ratih , RVS (2019) International Alliance Strategies: A Case Study of the Indonesian Medical Device Industry. In: Globalization and Development. Springer, pp. 381-400. ISBN 978-3-030-11766-5

http://repository.ubaya.ac.id/34825/ (In Access Date 11 June 2020).

Government Regulation No: 23, 2012 . Concerning Amendments to Government Regulation No: 23 of 2005 concerning Financial Management of Public Service Bodies.

https://jdih.kemenkeu.go.id/fullText/20 12/74TAHUN2012PP.htm (In Access Date 23 April 2020 ). 
Presidential Decree No: 16, 2018. Procurement of Government Goods and Services.

https://www.jogloabang.com/ekbis/perp res-16-2018-pengadaan-barangjasapemerintah. (In Access Date 29 April 2020 ).

Permenkes No: 3 , 2020. On Classification and Licensing Home Hospital . https://www.jogloabang.com/keseh/perm enkes-3-2020-klasifikasi-perizinan-rumahsakit. (In Access Date 29 April 2020 ).

Decree of the Minister of Health No : 756 , 2007 . About the Designation of 15 Hospitals for the Technical Implementation Unit of the Ministry of Health of the Republic of Indonesia by Implementing the Financial Management Pattern for Public Service Bodies

https://ruhyana.wordpress.com/2007/06 129/sistem-case-mix-ditetapkan-di-15rumah-sakit-vertikal/ (In Access Date 23 April 2020 ).

Vaillancourt , A. (2017). Procurement consolidation in humanitarian supply chains: a case study, vol. 10, issue 2, 178193.

https://www.researchgate.net/publicatio n/314981713_Procurement_consolidati on_in_humanitarian_supply_chains_A case_study (In Access Date 11 June 2020). 